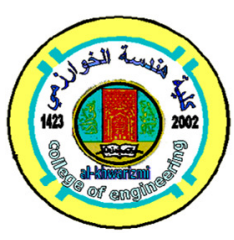

\title{
Buckling and Pre Stressed Dynamics Analysis of Laminated Compo- site Plate with Different Boundary Conditions
}

\author{
Widad I. Majeed* Zainab Abdul Kareem Abed ** \\ *,**Department of Mechanical Engineering/University of Baghdad \\ *Email: wedad.ibrahim@coeng.uobaghdad.edu.iq \\ **Email: zainabkareem2158@gmail.com
}

(Received 8 February 2018; accepted 4 July 2018)

https://doi.org/10.22153/kej.2019.07.002

\begin{abstract}
Critical buckling and natural frequencies behavior of laminated composite thin plates subjected to in-plane uniform load is obtained using classical laminated plate theory (CLPT). Analytical investigation is presented using Ritz- method for eigenvalue problems of buckling load solutions for laminated symmetric and anti-symmetric, angle and cross ply composite plate with different elastic supports along its edges. Equation of motion of the plate was derived using principle of virtual work and solved using modified Fourier displacement function that satisfies general edge conditions. Various numerical investigation were studied to exhibit a convergence and accuracy of the present solution for considering some design parameters such as edge conditions, aspect ratio, lamination angle, thickness ratio, orthotropic ratio, the results obtained gives good agreement with those published by other researchers.
\end{abstract}

Keywords: Buckling load, different boundary conditions, composite laminated plate, Free vibration, Rayleigh-Ritz method.

\section{Introduction}

The composite materials (C.M) reinforced by fiber are perfect for structural applications where high stiffness and strength to weight of ratios are necessary. Composite materials can be adapted to assemble the especial necessities of strength and stiffness by varying fiber orientations and lay-up. The capability to adapt a (C.M) to its work is very most important advantages of a (C.M) over a common material. In the past few decades the improvement and study of (C.M) in the mechanical, civil and aerospace structures design has developed.

The structures might be exposed to dynamic loads in difficult environmental conditions, so it is necessary to know the characteristic of vibrations. The cause of failure of the structure components when the natural frequencies of structure and the forcing frequency close to each other's which is the resonance (when structure damping is considered), may be occur large torsion $\backslash$ translation deflections and internal stresses. Many researchers have presented the stability of (C.M) subjected to buckling loads. [1]. Developed an exact solution on the base of the first order shear deformation theory (FSDT) to investigate the buckling behavior of symmetrical simply supported cross ply rectangular plates subjected to unidirectional linearly varying in-plane loads. [2]. Used a semianalytical attitude to the buckling analysis of symmetric laminated plates with general edge conditions. The multi-term extended Kantorovich method was used to decrease the partial differential of the equations of buckling to a solution of ordinary differential equations. [3]. Using the finite element method to study buckling and vibration of composite laminated plates with variable fiber spacing. [4]. Extended a two variable refined theory to the free vibration analysis of ortho- 
tropic plates using Navier's solution. [5]. Presented a study of buckling and post buckling behavior of simply supported composite plates subjected to non-uniform in-plane loading. The analytical solutions for laminated plate based on higher order shear deformation theory. The multiterm Galerkin method was used to solve the nonlinear partial differential equations governing post buckling behavior of plate. [6]. Investigated the natural frequencies and buckling of layered plates subjected to combined in-plane loadings with the aim of furnishing a few guidelines for the modeling and design of pre-stressed laminated panels. Different load conditions, stacking sequences, material properties and boundary conditions are considered. [7]. Presented a study of bending and free vibration analysis based on simple first order shear deformation theory (FSDT). Were the analytical solved by an exact method (Levy's method). [8]. Presented an exponential shear deformation theory which extended for buckling and free vibration analysis. The theory takes into account of transverse shear effects and parabolic distribution of the transverse shear strains through the thickness of the plate. Were the analytical solved by an exact method (Navier's method). [9]. Studied buckling behavior and free vibration of composite plates subjected to in plane parabolic, linear and uniform distributed loads using (CLPT). Analytical investigation is shows using Ritz method for eigenvalues problems of buckling loads solution for laminated plate. The edges conditions take into account are (SSSS, CCCC, SCSC, SFSF and CFCF). [10].The vibration and buckling of laminated beams studied by using a shear deformation and refined theory. The displacement field is estimated by using the Ritz technique. The functions used in the Ritz technique are chosen by way of either a hybrid polynomial-trigonometric series or a pure polynomial series.

\section{Buckling and Pre Stressed Vibration Analysis of Laminated Plates}

The governing equation is derived by using CPLT, [8]:

$\mathrm{D}_{11} \frac{\partial^{4} \mathrm{w}}{\partial \mathrm{x}^{4}}+\left(2 \mathrm{D}_{12}+4 \mathrm{D}_{66}\right) \frac{\partial^{4} \mathrm{w}}{\partial \mathrm{x}^{2} \partial \mathrm{y}^{2}}+\mathrm{D}_{22} \frac{\partial^{4} \mathrm{w}}{\partial \mathrm{x}^{4}}+$

$\mathrm{I}_{\mathrm{o}} \frac{\partial^{2} \mathrm{w}}{\partial \mathrm{t}^{2}}=\mathrm{N}_{\mathrm{x}} \frac{\partial^{2} \mathrm{w}}{\partial \mathrm{x}^{2}}$

Where, stress resultants are expressed in displacement form from below:
$\left(M_{x} \cdot M_{y} \cdot M_{x y}\right)=\int_{-h / 2}^{h / 2}\left(\sigma_{x}, \sigma_{y}, \sigma_{x y}\right) z d z=$

$\sum_{\mathrm{k}=1}^{\mathrm{N}} \int_{\mathrm{z}_{\mathrm{k}}}^{\mathrm{z}_{\mathrm{k}+1}}\left(\sigma_{\mathrm{x}}, \sigma_{\mathrm{y}}, \sigma_{\mathrm{xy}}\right) \mathrm{z} \mathrm{dz}$

$\mathrm{I}_{\mathrm{o}}=\int_{-\mathrm{h} / 2}^{\mathrm{h} / 2} \rho \mathrm{dz}$

Integrating Eq. (2), (3) through thickness of the plate, the stress resultant is associated to the displacement (w) by the relatives:

$$
\begin{aligned}
& \left\{\begin{array}{c}
\mathrm{M}_{\mathrm{x}} \\
\mathrm{M}_{\mathrm{y}} \\
\mathrm{M}_{\mathrm{xy}}
\end{array}\right\}=\left[\begin{array}{lll}
\mathrm{D}_{11} & \mathrm{D}_{12} & \mathrm{D}_{16} \\
\mathrm{D}_{12} & \mathrm{D}_{22} & \mathrm{D}_{26} \\
\mathrm{D}_{16} & \mathrm{D}_{26} & \mathrm{D}_{66}
\end{array}\right]\left\{\begin{array}{c}
\mathrm{k}_{\mathrm{x}} \\
\mathrm{k}_{\mathrm{y}} \\
\mathrm{k}_{\mathrm{xy}}
\end{array}\right\} \\
& \mathrm{D}_{\mathrm{ij}}=\left[\overline{\mathrm{Q}}_{\mathrm{ij}}\right] \int_{\frac{\mathrm{h}}{2}}^{\frac{-h}{2}} \mathrm{z}^{2} \mathrm{dz}
\end{aligned}
$$

The twisting moments and bending, transversal shear forces can be written in terms of the displacement function as, [11].

$$
\begin{aligned}
& \mathrm{M}_{\mathrm{x}}=-\mathrm{D}_{11} \frac{\partial^{2} \mathrm{w}}{\partial \mathrm{x}^{2}}-\mathrm{D}_{12} \frac{\partial^{2} \mathrm{w}}{\partial \mathrm{y}^{2}} \\
& \mathrm{M}_{\mathrm{y}}=-\mathrm{D}_{22} \frac{\partial^{2} \mathrm{w}}{\partial \mathrm{y}^{2}}-\mathrm{D}_{12} \frac{\partial^{2} \mathrm{w}}{\partial \mathrm{x}^{2}} \\
& \mathrm{M}_{\mathrm{xy}}=-2 \mathrm{D}_{66} \frac{\partial^{2} \mathrm{w}}{\partial \mathrm{x} \partial \mathrm{y}} \\
& \mathrm{Q}_{\mathrm{x}}=-\mathrm{D}_{11} \frac{\partial^{3} \mathrm{w}}{\partial \mathrm{x}^{3}}-\left(\mathrm{D}_{12}+4 \mathrm{D}_{66}\right) \frac{\partial^{3} \mathrm{w}}{\partial \mathrm{y}^{2} \partial \mathrm{x}} \\
& \mathrm{Q}_{\mathrm{x}}=-\mathrm{D}_{22} \frac{\partial^{3} \mathrm{w}}{\partial \mathrm{y}^{3}}-\left(\mathrm{D}_{12}+4 \mathrm{D}_{66}\right) \frac{\partial^{3} \mathrm{w}}{\partial \mathrm{x}^{2} \partial \mathrm{y}}
\end{aligned}
$$

For a flexibly restricted rectangular plate shown in Fig.(1), the boundary conditions are :

$$
\begin{aligned}
& \mathrm{k}_{\mathrm{x} 0} \mathrm{~W}=\mathrm{Q}_{\mathrm{x}} \quad \mathrm{K}_{\mathrm{x} 0} \frac{\partial \mathrm{w}}{\partial \mathrm{x}}=-\mathrm{M}_{\mathrm{x}} \\
& \mathrm{x}=0 \\
& \mathrm{k}_{\mathrm{x} 1} \mathrm{w}=-\mathrm{Q}_{\mathrm{x}} \\
& \mathrm{K}_{\mathrm{x} 1} \frac{\partial \mathrm{w}}{\partial \mathrm{x}}=-\mathrm{M}_{\mathrm{x}} \quad \ldots(11-12) \\
& \mathrm{x}=\mathrm{a} \\
& \mathrm{k}_{\mathrm{y} 0} \mathrm{w}=\mathrm{Q}_{\mathrm{y}} \\
& \mathrm{y}=0 \\
& \mathrm{k}_{\mathrm{y} 1} \mathrm{w}=-\mathrm{Q}_{\mathrm{y}} \\
& \mathrm{K}_{\mathrm{y} 0} \frac{\partial \mathrm{w}}{\partial \mathrm{y}}=-\mathrm{M}_{\mathrm{y}} \\
& \mathrm{K}_{\mathrm{y} 1} \frac{\partial \mathrm{w}}{\partial \mathrm{y}}=-\mathrm{M}_{\mathrm{y}}
\end{aligned}
$$

Where $\mathrm{k}_{\mathrm{y} 0} \mathrm{k}_{\mathrm{y} 1}$ and $\mathrm{k}_{\mathrm{x} 0} \mathrm{k}_{\mathrm{x} 1}$ are the transitional stiffness of spring, $\mathrm{K}_{\mathrm{y} 0} \mathrm{~K}_{\mathrm{y} 1}$ and $\mathrm{K}_{\mathrm{x} 0}, \mathrm{~K}_{\mathrm{x} 1}$ are the rotations stiffness of spring. Eq.(11)-(18) express for different edge conditions, the classic homogeneously edge conditions can be direct obtained by putting the constants of spring equalize to an very small or large number.

By substituting Eq. (6-10) in Eq. (11-18), get the following equations:

$$
\begin{aligned}
& \mathrm{k}_{\mathrm{x} 0} \mathrm{w}=-\mathrm{D}_{11} \frac{\partial^{3} \mathrm{w}}{\partial \mathrm{x}^{3}}-\left(\mathrm{D}_{12}+4 \mathrm{D}_{66}\right) \frac{\partial^{3} \mathrm{w}}{\partial \mathrm{y}^{2} \partial \mathrm{x}} \\
& \mathrm{k}_{\mathrm{x} 1} \mathrm{w}=\mathrm{D}_{11} \frac{\partial^{3} \mathrm{w}}{\partial \mathrm{x}^{3}}+\left(\mathrm{D}_{12}+4 \mathrm{D}_{66}\right) \frac{\partial^{3} \mathrm{w}}{\partial \mathrm{y}^{2} \partial \mathrm{x}} \\
& \mathrm{K}_{\mathrm{x} 0} \frac{\partial \mathrm{w}}{\partial \mathrm{x}}=\mathrm{D}_{11} \frac{\partial^{2} \mathrm{w}}{\partial \mathrm{x}^{2}}+\mathrm{D}_{12} \frac{\partial^{2} \mathrm{w}}{\partial \mathrm{y}^{2}} \\
& \mathrm{~K}_{\mathrm{x} 1} \frac{\partial \mathrm{w}}{\partial \mathrm{x}}=\mathrm{D}_{11} \frac{\partial^{2} \mathrm{w}}{\partial \mathrm{x}^{2}}+\mathrm{D}_{12} \frac{\partial^{2} \mathrm{w}}{\partial \mathrm{y}^{2}}
\end{aligned}
$$

And similarly found other four equations in the y direction. 


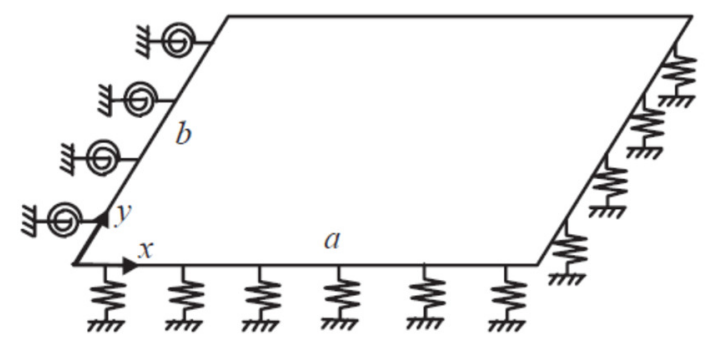

Fig. 1. Elastic restrained edges for a rectangular plate [12].

As mentioned by many plate and shell researches that exact solution for plate or shell with general boundary conditions is not available so we use Ritz method to get approximate solution from Hamilton's equation:

$$
\delta \iiint(\mathrm{U}-\mathrm{W}+\mathrm{T})=0
$$

Where $U$ is the strain energy, $\mathrm{W}$ is potential energy due to the external forces and $\mathrm{T}$ is the kinetic energy. $\delta$ the random variation.

Where

$\mathrm{U}=\int_{\frac{-\mathrm{h}}{2}}^{\frac{\mathrm{h}}{2}} \int_{0}^{\mathrm{b}} \int_{0}^{\mathrm{a}}\left(\sigma_{\mathrm{x}} \varepsilon_{\mathrm{x}}+\sigma_{\mathrm{y}} \varepsilon_{\mathrm{y}}+\tau_{\mathrm{xy}} \gamma_{\mathrm{xy}}\right) \mathrm{dxdydz}+$

Elastic energy of springs at edges

$\mathrm{W}=\frac{1}{2} \int_{0}^{\mathrm{b}} \int_{0}^{\mathrm{a}}\left[\mathrm{N}_{\mathrm{x}}\left(\frac{\partial \mathrm{w}}{\partial \mathrm{x}}\right)^{2}\right] \mathrm{dx} \mathrm{dy}$

$\mathrm{T}=\rho \int_{\frac{-\mathrm{h}}{2}}^{\frac{\mathrm{h}}{2}} \int_{0}^{\mathrm{b}} \int_{0}^{\mathrm{a}}\left[\frac{\partial^{2} \mathrm{w}}{\partial \mathrm{t}^{2}} \mathrm{w}\right] \mathrm{dx} d \mathrm{ydz}$

Substituting Eqs.(2- 4),(19-22) in Eq.(24),yield to:

$\mathrm{U}-\mathrm{W}=\frac{1}{2} \int_{0}^{\mathrm{b}} \int_{0}^{\mathrm{a}}\left[\mathrm{D}_{11}\left(\frac{\partial^{2} \mathrm{w}}{\partial \mathrm{x}^{2}}\right)^{2}+\mathrm{D}_{22}\left(\frac{\partial^{2} \mathrm{w}}{\partial \mathrm{y}^{2}}\right)^{2}+\right.$

$\left.4 \mathrm{D}_{66}\left(\frac{\partial^{2} \mathrm{w}}{\partial \mathrm{x} \partial \mathrm{y}}\right)^{2}+2 \mathrm{D}_{12} \frac{\partial^{2} \mathrm{w}}{\partial \mathrm{x}^{2}} \frac{\partial^{2} \mathrm{w}}{\partial \mathrm{y}^{2}}\right] \mathrm{dxdy}+$

$\frac{1}{2} \int_{0}^{\mathrm{b}}\left[\mathrm{k}_{\mathrm{x} 0} \mathrm{w}^{2}+\right.$

$\left.\mathrm{K}_{\mathrm{x} 0}\left(\frac{\partial \mathrm{w}}{\partial \mathrm{x}}\right)^{2}\right]_{\mathrm{x}=0} \mathrm{dy}+\frac{1}{2} \int_{0}^{\mathrm{b}}\left[\mathrm{k}_{\mathrm{x} 1} \mathrm{w}^{2}+\right.$

$\left.\mathrm{K}_{\mathrm{x} 1}\left(\frac{\partial \mathrm{w}}{\partial \mathrm{x}}\right)^{2}\right]_{\mathrm{x}=\mathrm{a}} \mathrm{dy}+\frac{1}{2} \int_{0}^{\mathrm{a}}\left[\mathrm{k}_{\mathrm{y} 0} \mathrm{w}^{2}+\right.$

$\left.\mathrm{K}_{\mathrm{y} 0}\left(\frac{\partial \mathrm{w}}{\partial \mathrm{y}}\right)^{2}\right]_{\mathrm{y}=0}^{\mathrm{dx}} \mathrm{dx}+\frac{1}{2} \int_{0}^{\mathrm{a}}\left[\mathrm{k}_{\mathrm{y} 1} \mathrm{w}^{2}+\right.$

$\left.\mathrm{K}_{\mathrm{y} 1}\left(\frac{\partial \mathrm{w}}{\partial \mathrm{y}}\right)^{2}\right]_{\mathrm{y}=\mathrm{b}} \mathrm{dx}-\frac{1}{2} \int_{0}^{\mathrm{b}} \int_{0}^{\mathrm{a}}\left[\mathrm{N}_{\mathrm{x}}\left(\frac{\partial \mathrm{w}}{\partial \mathrm{x}}\right)^{2}\right] \mathrm{dx} d \mathrm{y}$

and

\section{Admissible Functions}

With Ritz method the allowable functions play an important part. The products of beam functions are commonly selected like the displacement function and functions can be consequently like, [12].

$\mathrm{w}(\mathrm{x} y)=\sum_{\mathrm{m} n=1} \mathrm{~A}_{\mathrm{mn}} \mathrm{X}(\mathrm{x}) \mathrm{Y}(\mathrm{y})$

WhereX $(\mathrm{x}), \mathrm{Y}(\mathrm{y})$ are the specific variables for beams that include a similar edge conditions in the $(y, x)$ direction, correspondingly.

The beam functions can be in general achieved like a linear collection of hyperbolic and trigonometric functions, which involve some unknown variables which are exist from the edge conditions. Then, every edge conditions essentially conduct to a various beam functions. In actual uses, this is obviously disadvantageous, beside the damage of computing the specific functions for a different boundary beam. with a view to avert this difficulty, an developed the series of Fourier technique has been suggested for beams with different boundaries at each ends in which the specific functions are written in the form of, [13].

$\mathrm{w}(\mathrm{x})=\sum_{\mathrm{m}=0}^{\infty} \mathrm{a}_{\mathrm{m}} \cos \lambda_{\mathrm{am}} \mathrm{x}+\mathrm{P}(\mathrm{x})$

$\left(\lambda_{\mathrm{am}}=\frac{\mathrm{m} \pi}{\mathrm{a}}\right), \quad 0 \leq \mathrm{x} \leq \mathrm{a}$

$\mathrm{P}(\mathrm{x})$ is the function in Eq. (28) considers an arbitrarily continued function that, in any case of edge conditions, is constantly selected to satisfy the equations as following:

$$
\begin{aligned}
& \mathrm{P}^{\prime \prime \prime}(0)=\mathrm{W}^{\prime \prime \prime}(0)=\alpha_{0} . \quad \mathrm{P}^{\prime \prime \prime}(\mathrm{a})=\mathrm{W}^{\prime \prime \prime}(\mathrm{a})= \\
& \alpha_{1} \\
& \mathrm{P}^{\prime}(0)=\mathrm{W}^{\prime}(0)=\beta_{0} \text {. and } \\
& \text {... (29-30) } \\
& \beta_{1} \\
& \mathrm{P}^{\prime}(\mathrm{a})=\mathrm{W}^{\prime}(\mathrm{a})=
\end{aligned}
$$

$\mathrm{P}(\mathrm{x})$ is here inserted to take care of the latent discontinuities of the function of displacement and its derivative at end points. Accurately, previously it is known that the smoothest a periodical function, the quicker its Fourier extension convergence. Thus, adding of the $\mathrm{P}(\mathrm{x})$ will have two instantaneous interests: (1) the series of Fourier extension is presently agreed with any edge conditions, and (2) the solution of the series of Fourier its accurateness of convergences.

Yet, $\mathrm{P}(\mathrm{x})$ have just been realized as a continuously function that satisfy Eq. (29) - (32), the function $\mathrm{P}(\mathrm{x})$ format is not a worry with regard to the convergences of the series solution. Therefore, it can be chosen in any required formula. Like a substantiation, supposes the $\mathrm{P}(\mathrm{x})$ is a the function of polynomial,

$\mathrm{P}(\mathrm{x})=\sum_{\mathrm{n}=0}^{4} \mathrm{C}_{\mathrm{n}} \mathrm{P}_{\mathrm{n}}\left(\frac{\mathrm{x}}{\mathrm{a}}\right)$.

Where $P_{n}(x)$ is the Legendre function of order $\mathrm{n}, \mathrm{C}_{\mathrm{n}}$ is the coefficient of extension.

It is clarifies that $\mathrm{P}(\mathrm{x})$ desires to be minimum a $4^{\text {th }}$ polynomial to jointly satisfy Eq.(29) - (32). Substituting Eq. (33) into Eq. (29) - (32) results yield to: 


$$
\begin{array}{ll}
\mathrm{C}_{3} \mathrm{P}_{3}^{\prime \prime \prime}(0)+\mathrm{C}_{4} \mathrm{P}_{4}^{\prime \prime \prime}(0)=\mathrm{a}^{3} \alpha_{0} . & \ldots(34) \\
\mathrm{C}_{3} \mathrm{P}_{3}^{\prime \prime \prime}(1)+\mathrm{C}_{4} \mathrm{P}_{4}^{\prime \prime \prime}(1)=\mathrm{a}^{3} \alpha_{1} . & \ldots(35) \\
\mathrm{C}_{1} \mathrm{P}_{1}^{\prime}(0)+\mathrm{C}_{2} \mathrm{P}_{2}^{\prime}(0)+\mathrm{C}_{3} \mathrm{P}_{3}^{\prime}(0)+\mathrm{C}_{4} \mathrm{P}_{4}^{\prime}(0)=\mathrm{a} \beta_{0} . \\
\\
\mathrm{C}_{1} \mathrm{P}_{1}^{\prime}(1)+\mathrm{C}_{2} \mathrm{P}_{2}^{\prime}(1)+\mathrm{C}_{3} \mathrm{P}_{3}^{\prime}(1)+\mathrm{C}_{4} \mathrm{P}_{4}^{\prime}(1)=\mathrm{a} \beta_{1} .
\end{array}
$$

By using the above equations, the coefficients, $\mathrm{C}_{1} \cdot \mathrm{C}_{2} \cdot \mathrm{C}_{3}$ and $\mathrm{C}_{4}$ are straight acquired in terms of the edge constants, $\alpha_{0} . \alpha_{1} \cdot \beta_{0}$. then $\beta_{1}$. As the coefficient $C_{0}$ doesn't really seem in Eq. (34) -(37), it can be a random number theoretically. For example, $\mathrm{C}_{0}$ is presently chosen to content

$\int_{0}^{a} \mathrm{P}(\mathrm{x}) \mathrm{dx}=0$

The last appearance for the $\mathrm{P}(\mathrm{x})$ can be shown as

$\mathrm{P}(\mathrm{x})=\zeta_{\mathrm{a}}(\mathrm{x})^{\mathrm{T}} \overline{\boldsymbol{\alpha}}$

Where

$\overline{\boldsymbol{\alpha}}=\left\{\alpha_{0} \cdot \alpha_{1} \cdot \beta_{0} \cdot \beta_{1}\right\}^{\mathrm{T}}$

Where

$$
\mathrm{H}_{\mathrm{a}}=\left[\begin{array}{c}
1+\frac{8 \mathrm{k}_{\mathrm{x} 0} \mathrm{a}^{3}}{360 \mathrm{D}_{1}} \\
\frac{7 \mathrm{k}_{\mathrm{x} 1} \mathrm{a}^{3}}{360 \mathrm{D}_{11}} \\
\frac{\mathrm{a}}{3} \\
\frac{\mathrm{a}}{6}
\end{array}\right.
$$$$
\begin{gathered}
\frac{7 \mathrm{k}_{\mathrm{x} 0} \mathrm{a}^{3}}{360 \mathrm{D}_{11}} \\
1+\frac{8 \mathrm{k}_{\mathrm{x} 1} \mathrm{a}^{3}}{360 \mathrm{D}_{11}} \\
\frac{\mathrm{a}}{6} \\
\frac{\mathrm{a}}{3}
\end{gathered}
$$$$
\frac{-\mathrm{k}_{\mathrm{x} 0} \mathrm{a}}{3 \mathrm{D}_{11}}
$$$$
\frac{-\mathrm{k}_{\mathrm{x} 1}}{3 \mathrm{D}_{11}}
$$$$
\frac{\mathrm{K}_{\mathrm{x} 0}}{\mathrm{D}_{11}}+\frac{1}{\mathrm{a}}
$$$$
\frac{-1}{a}
$$

and

$$
\begin{aligned}
& \mathrm{Q}_{\mathrm{am}}=\left\{(-1) \frac{\mathrm{k}_{\mathrm{x} 0}}{\mathrm{D}_{11}} \quad(-1)^{\mathrm{m}} \frac{\mathrm{k}_{\mathrm{x} 1}}{\mathrm{D}_{11}} \quad-\right. \\
& \left.\lambda_{\mathrm{am}}^{2}(-1)^{\mathrm{m}} \lambda_{\mathrm{am}}^{2}\right\}^{\mathrm{T}}
\end{aligned}
$$

It must be reminded that a matrix Ha becomes single to a totally free Beam, [14],

. By using of Eqs. (39) and (42), Eq. (28) becomes as:

$$
\mathrm{w}(\mathrm{x})=\sum_{\mathrm{m}=0}^{\infty} \mathrm{a}_{\mathrm{m}} \varphi_{\mathrm{m}}^{\mathrm{a}}(\mathrm{x})
$$

Where

$$
\varphi_{\mathrm{m}}^{\mathrm{a}}(\mathrm{x})=\cos \lambda_{\mathrm{am}} \mathrm{x}+\zeta_{\mathrm{a}}(\mathrm{x}) \mathrm{H}_{\mathrm{a}}^{-1} \mathrm{Q}_{\mathrm{am}}
$$

Mathematically, Eq. (45) mention that every of the functions of the beam can be observed as a function in the functional space spanned by the base functions $\left\{\varphi_{\mathrm{m}}^{\mathrm{a}}(\mathrm{x}): \mathrm{m}=0.1 .2 \ldots \ldots \ldots\right\}$. So, Eq.(27) can be consequently rewritten as:

$\mathrm{w}(\mathrm{x} . \mathrm{y})=\sum_{\mathrm{m} . \mathrm{n}=0}^{\infty} \mathrm{A}_{\mathrm{m}} \varphi_{\mathrm{m}}^{\mathrm{a}}(\mathrm{x}) \varphi_{\mathrm{n}}^{\mathrm{b}}(\mathrm{y})$

Where:

$$
\varphi_{\mathrm{n}}^{\mathrm{b}}(\mathrm{y})=\cos \lambda_{\mathrm{bn}} \mathrm{y}+\zeta_{\mathrm{b}}(\mathrm{y}) \mathrm{H}_{\mathrm{b}}^{-1} \mathrm{Q}_{\mathrm{bn}}
$$

The terms for $\zeta_{\mathrm{b}}(\mathrm{y})$. $\mathrm{H}_{\mathrm{b}}$ and $\mathrm{Q}_{\mathrm{bn}}$ can be, correspondingly, obtained from Eqs. (41), (43) and (44) by easily changing the $\mathrm{x}$ - regarding parameters by the $y$ - regarding.

$$
\begin{aligned}
& \text { and } \\
& \zeta_{a}(x)^{T} \\
& =\left\{\begin{array}{c}
-\left(15 x^{4}-60 a x^{3}+60 a^{2} x^{2}-8 a^{4}\right) / 360 a \\
\left(15 x^{4}-30 a^{2} x^{2}+7 a^{4}\right) / 360 a \\
\left(6 a x-2 a^{2}-3 x^{2}\right) / 6 a \\
\left(3 x^{2}-a^{2}\right) / 6 a
\end{array}\right\}
\end{aligned}
$$

The results in Eq. (39) - (41) are already derived from an additional simple but little common approach, [12].

So as to obtain the unknown of edge constants, $\alpha_{0} \cdot \alpha_{1} \cdot \beta_{0}$. and $\beta_{1}$. substitution of Eq. (28) and eq. (39) into the edge conditions Eq. (19)-(22) that results in

$$
\overline{\boldsymbol{\alpha}}=\sum_{\mathrm{m}=0}^{\infty} \mathrm{H}_{\mathrm{a}}^{-1} \mathrm{Q}_{\mathrm{am}} \mathrm{a}_{\mathrm{m}}
$$

$$
\left.\begin{array}{c}
\frac{-\mathrm{k}_{\mathrm{x} 0} \mathrm{a}}{6} \\
\frac{-\mathrm{k}_{\mathrm{x} 1} \mathrm{a}}{6} \\
\frac{-1}{\mathrm{a}} \\
\frac{\mathrm{K}_{\mathrm{x} 1}}{\mathrm{D}_{11}}+\frac{1}{\mathrm{a}}
\end{array}\right]
$$

\section{Eigen Value Problem}

Orthotropic plate are consider, the material directions of width identify with the plate directions. Uniaxial in-plane compressive force $\mathrm{N}_{\mathrm{x}}$ along the both sides of edge $(\mathrm{x})$ is subjected.

To calculate the critical buckling load; the natural frequency $\omega$ is set to zero, to find the natural frequency without the action of buckling load; $N_{x}$ is set to zero, and to calculate the natural frequency under buckling load action; ; $\mathrm{N}_{\mathrm{X}}$ is left as a known after finding the critical buckling load $\mathrm{N}_{\mathrm{cr}}$ Previously. Performing the required mathematical processes (differentiations and then integrations) of Eq.(25) and(26) and then putting the mechanical energy in the following equation:

$\frac{\partial \mathrm{E}}{\partial \mathrm{A}_{\mathrm{mn}}}=0$

Eq. (48) gives homogenous equations as follow1;

$\mathrm{f}\left(\mathrm{A}_{\mathrm{mn}} \cdot \mathrm{N}_{\mathrm{cr}}\right)=0$ for buckling problem

$\mathrm{f}\left(\mathrm{A}_{\mathrm{mn}} \cdot \omega\right)=0$ for vibration problem

$\mathrm{f}\left(\mathrm{A}_{\mathrm{mn}} \cdot \mathrm{N}_{\mathrm{xx}} \cdot \omega\right)=0$ for vibration under bucklin... (50)

Eq. (50) solving as an Eigen-value problem which is written as below:

$\left[\begin{array}{ccc}\mathrm{a}_{1.1} & \cdots & \mathrm{a}_{1 .(\mathrm{m} * \mathrm{n})} \\ \vdots & \ddots & \vdots \\ \mathrm{a}_{(\mathrm{m} * \mathrm{n}) \cdot 1} & \cdots & \mathrm{a}_{(\mathrm{m} * \mathrm{n}) \cdot(\mathrm{m} * \mathrm{n})}\end{array}\right]\left\{\begin{array}{c}\mathrm{A}_{11} \\ \vdots \\ \mathrm{A}_{\mathrm{mn}}\end{array}\right\}=0$

Where $a_{i j}$ are the coefficients of the nonzero 
unknowns $A_{m n}$. Finding the determinant of the first term of Eq.(51) and equating it to zero will lead to get the natural frequencies $\omega$ and critical buckling load $N_{c r}$. When $\mathrm{M}$ and $\mathrm{N}$ are more than 1 , The $N_{c r}$ and $\omega$ are determined by solving eigenvalue problem. For different edge conditions and $\mathrm{M} \& \mathrm{~N}$ more than 1 , the solution becomes more difficult and needs computer programming to determine $N_{c r}$. In this study MATLAP R2015a is used to solve the eigenvalue problem to find the natural frequency under buckling action. For numerical study, ANSYS APDL programming is used.

\section{Results and Discussion}

MATLAP (version15) programming is used to investigate and solved the buckling load and natural frequency under buckling of composite laminated plate (CLP) with elastic edge condition. The plates are described by a four-letter symbol for example SCSC denotes a plate with simply supported edge at $\mathrm{y}=\mathrm{b}, \mathrm{y}=0$, clamped at $\mathrm{x}=\mathrm{a}, \mathrm{x}=0$. To see the validly of the derived equations and performance of computer programming for buckling and vibration analysis of (CLP), orthotropic plate numerical results are compared with those found by Firas Hamzah Taya, 2014 [9]. And I. Shufrin, O. Rabinovitch, M. Eisenberger, 2008 [2].Table $(1,2)$ shows a good agreement results for different edge conditions. It show that the clamped plate along two or four edges can hold buckling load more than plate with simply supported boundary conditions, especially in table (1) for the case where the plate is FSFS. In the case where the plate is simply supports or mixed with free edges, it is weak to hold large load compared with clamped plates. While show results for laminated composite plate with different edge conditions, stacking sequence, aspect ratio and modulus ratio give good agreement when compared with $\mathrm{J}$. N. Reddy, 2003[15] and I. Shufrin, O. Rabinovitch, M. Eisenberger, 2008[2]. As shown in Table (3, 4, 5). Table (6) present the results of anti-symmetric cross and angle ply with different aspect and modulus ratio and give a good agreement when compared with results obtained by J. N. Reddy, 2003. Table (7) shows the results of the natural frequency of laminated plate under buckling for different load ratio and compered with the results obtained by Firas Hamzah Taya, 2014, give very close results. It shows that the natural frequency is less than that found without loading because the stiffness reduction. In table $(8,9,11)$ show the results of the natural frequency under buckling for different load ratio and compared with the results obtained by numerical program ANSYS, also in table (10) show the natural frequency under load ratio $(\mathrm{d}=0.5)$ with effect of aspect, modulus ratio and Fig.2. shows the mode shapes of the case.

\section{Conclusions}

Buckling of rectangular laminated plate with general elastic restraints along the edges is obtained by using modified Fourier function; also free vibration of this plate under in plane loading is investigated using Rayleigh-Ritz method. The results are compared with the results obtained by other researchers; the comparison showed good agreement between them. The effect of edge conditions, aspect ratio, lamination system, angle of lamination and load correction factor on buckling and vibration characteristics are studied. From the result it is concluded that, the buckling load decreases rapidly with increasing aspect ratio till it is about 1.5, after that takes constancy or close values for higher aspect ratio. The edge conditions affect the critical buckling load and fundamental natural frequency. Clamped edges conditions offer high stiffness, results in high critical buckling load and natural frequency. Clamped edges make the plate holds larger load than simply supported edges. The natural frequency changes reversely with buckling load ratio. Therefore, this investigation has actually showed that this function can be used to get buckling and vibration characteristics of laminated plate with various boundary conditions.

Table 1,

Non-dimensional buckling $\operatorname{load}\left(\bar{N}=N_{c r} b^{2} / E_{2} h^{3}\right)$, for [0 90 0] plates of different Boundary conditions, $\left(E_{1} / E_{2}=10, G_{12}=0.6 E_{2}, v_{12}=0.25, a=b\right)$.

\begin{tabular}{llllll}
\hline \multirow{2}{*}{ References } & \multicolumn{2}{l}{ Type of boundary conditions } & & & \\
& SSSS & CCCC & SCSC & FSFS & FCFC \\
\hline Present work & 11.550 & 40.38 & 35.900 & 8.049 & 32.544 \\
Firas[9] & 11.491 & 40.507 & 36.255 & 7.991 & 32.982 \\
\hline
\end{tabular}


Table 2,

Non-dimensional buckling load $\left(\bar{N}=N_{c r} 12\left(1-v_{12} v_{21}\right) / E_{1} h^{3}\right)$, for [30 -30 30] plates of different boundary conditions, $\left(E_{1} / E_{2}=2.45, G_{12}=0.48 E_{2}, v_{12}=0.23 \mathrm{a}=\mathrm{b}\right)$.

\begin{tabular}{lllll}
\hline \multirow{2}{*}{ References } & \multicolumn{2}{c}{ Type of boundary conditions } & & SCSC \\
\hline Present work & SSSS & CCCC & CSCS & 39.32 \\
I. Shufrin[2] & 25.77 & 66.81 & 47.33 & 40.93 \\
Discrepancy \% & 26.67 & 65.26 & 49.18 & 4 \\
\hline
\end{tabular}

Table 3,

Non-dimensional buckling $\operatorname{load}\left(\bar{N}=N_{c r} b^{2} / D_{22} \pi^{2}\right)$, for [0 9090 0] plates (SSSS) of different aspect, modulus ratio, $\left(G_{12}=0.5 E_{2}, v_{12}=0.25\right)$.

\begin{tabular}{lllllll}
\hline References & $\mathbf{a} / \mathbf{b}$ & $\boldsymbol{E}_{\mathbf{1}} / \boldsymbol{E}_{\mathbf{2}} \mathbf{= 5}$ & $\mathbf{1 0}$ & $\mathbf{2 0}$ & $\mathbf{2 5}$ & $\mathbf{4 0}$ \\
\hline Present work & & 13.94 & 18.225 & 22 & 23.1 & 25 \\
Reddy[16] & 0.5 & 13.9 & 18.126 & 21.87 & 22.87 & 24.59 \\
Present work & & 5.66 & 6.353 & 7 & 7.13 & 7.5 \\
Reddy & 1 & 5.65 & 6.347 & 6.96 & 7.12 & 7.4 \\
Present work & & 5.238 & 5.28 & 5.317 & 5.326 & 5.34 \\
Reddy & 1.5 & 5.233 & 5.27 & 5.31 & 5.318 & 5.33 \\
\hline
\end{tabular}

Table 4,

Non-dimensional buckling $\operatorname{load}\left(\bar{N}=N_{c r} b^{2} / D_{22} \pi^{2}\right)$, for $[090]_{2 s}$ laminated plates (CCCF) of different aspect, modulus ratio, $\left(G_{12}=0.5 E_{2}, v_{12}=0.25\right)$.

\begin{tabular}{lllcl}
\hline $\boldsymbol{E}_{\mathbf{1}} / \boldsymbol{E}_{\mathbf{2}}$ & References & $\boldsymbol{a} / \boldsymbol{b}=\mathbf{1}$ & $\mathbf{1 . 5}$ & $\mathbf{2}$ \\
\hline \multirow{3}{*}{3} & Present work & 6.7 & 3.48 & 2.47 \\
& I. Shufrin & 6.4 & 3.3 & 2.34 \\
& Discrepancy\% & 4.7 & 5 & 5 \\
$\mathbf{1 0}$ & Present work & 8.08 & 3.96 & 2.6 \\
& I. Shufrin & 7.84 & 3.78 & 2.48 \\
\end{tabular}

Table 5,

Non-dimensional buckling $\operatorname{load}\left(\bar{N}=N_{c r} b^{2} / D_{22} \pi^{2}\right)$, for $\left[\begin{array}{ll}0 & 90\end{array}\right]_{2 s}$ laminated plates (CSCS) of different aspect, modulus ratio, $\left(G_{12}=0.5 E_{2}, v_{12}=0.25\right)$.

\begin{tabular}{lllll}
\hline$\frac{\boldsymbol{E}_{\mathbf{1}}}{\boldsymbol{E}_{\mathbf{2}}}$ & References & $\boldsymbol{a} / \boldsymbol{b}=\mathbf{1}$ & $\mathbf{1 . 5}$ & $\mathbf{2}$ \\
\hline \multirow{3}{*}{} & Present work & 6.671 & 6.379 & 6.12 \\
& I. Shufrin & 6.659 & 6.295 & 5.84 \\
$\mathbf{1 0}$ & Discrepancy\% & 0.179 & 1.3 & 4.5 \\
& Present work & 6.584 & 6.096 & 5.71 \\
& I. Shufrin & 6.557 & 6.056 & 5.46 \\
\hline
\end{tabular}

Table 6,

Non-dimensional buckling $\operatorname{load}\left(\bar{N}=N_{c r} b^{2} / E_{2} h^{3}\right)$, for anti-symmetric laminated plates (SSSS) with effect of different modulus ratio, $\left(G_{12}=0.5 E_{2}, v_{12}=0.25\right)$.

\begin{tabular}{|c|c|c|c|c|}
\hline $\begin{array}{l}\text { Ply } \\
\text { Orientations }\end{array}$ & References & $E_{1} / E_{2}=10$ & 25 & 40 \\
\hline \multirow{3}{*}[\begin{array}{ll}{0}&{90}\end{array}]{$_{4}$} & Present work & 11.174 & 23.523 & 35.874 \\
\hline & Reddy & 10.864 & 22.622 & 34.381 \\
\hline & Discrepancy\% & 2.7 & 3.8 & 4.1 \\
\hline \multirow{3}{*}[45-45]{$_{4}$} & Present work & 18.2 & 42.81 & 67.38 \\
\hline & Reddy & 17.637 & 41.16 & 64.68 \\
\hline & Discrepancy\% & 3 & 3.8 & 4 \\
\hline
\end{tabular}


Table 7,

Dimensionless natural frequency $\left(\bar{\omega}=\omega_{o} a^{2} \sqrt{\rho_{c} / E_{2}} / h\right)$, for [0 90 0] plates under buckling of different load rati$\mathrm{os},\left(E_{1} / E_{2}=10, G_{12}=0.6 E_{2}, v_{12}=0.25, a=b\right)$.

\begin{tabular}{lllllll}
\hline $\mathrm{D}$ & References & SSSS & CCCC & CSCS & SFSF & CFCF \\
\hline \multirow{2}{*}{0} & Present work & 10.656 & 22.255 & 21.065 & 8.892 & 20.106 \\
& Firas & 10.649 & 22.323 & 21.119 & 8.886 & 20.143 \\
\multirow{2}{*}{0.25} & Present work & 9.228 & 19.27 & 18.243 & 7.701 & 17.413 \\
& Firas & 9.223 & 19.33 & 18.29 & 7.443 & 17.444 \\
\multirow{2}{*}{0.5} & Present work & 7.535 & 15.736 & 14.895 & 6.287 & 14.217 \\
\multirow{2}{*}{0.75} & Firas & 7.53 & 15785 & 14.933 & 5.973 & 14.243 \\
& Present work & 5.328 & 11.127 & 10.532 & 4.446 & 10.053 \\
& Firas & 5.324 & 11.161 & 10.559 & 3.995 & 10.071 \\
\hline
\end{tabular}

Table 8,

Dimensionless natural frequency $\left(\bar{\omega}=\omega_{o} a^{2} \sqrt{\rho_{c} / E_{2}} / h\right)$, for [0 9090 0] plates under buckling of different load $\underline{\operatorname{ratios},\left(E_{1} / E_{2}=40, G_{12}=0.5 E_{2}, v_{12}=0.25, a=b\right)}$.

\begin{tabular}{llllll}
\hline $\mathbf{d}$ & References & SSSS & CCCC & SCSC & SFSF \\
\hline \multirow{3}{*}{} & Present work & 18.817 & 41.216 & 38.668 & 6.916 \\
& Ansys & 18.703 & 40.662 & 38.099 & 6.914 \\
$\mathbf{0 . 2 5}$ & Present work & 16.296 & 35.695 & 33.488 & 6.916 \\
& Ansys & 16.196 & 35.434 & 33.169 & 6.902 \\
$\mathbf{0 . 5}$ & Present work & 13.306 & 29.145 & 27.343 & 5.812 \\
& Ansys & 13.224 & 29.14 & 27.244 & 5.813 \\
$\mathbf{0 . 7 5}$ & Present work & 9.408 & 20.609 & 19.335 & 4.11 \\
\hline
\end{tabular}

Table 9,

Dimensionless natural frequency $\left(\bar{\omega}=\omega_{o} a^{2} \sqrt{\rho_{c} / E_{2}} / h\right)$, for [45 - 45] plates under buckling of different load ratios, $\left(E_{1} / E_{2}=10, G_{12}=0.5 E_{2}, v_{12}=0.25, a=b\right)$.

\begin{tabular}{llllll}
\hline $\mathbf{D}$ & References & SSSS & CCCC & SCSC & SFSF \\
\hline \multirow{2}{*}{0} & Present work & 1.409 & 21.632 & 17.914 & 5.252 \\
& Ansys & 13.111 & 21.165 & 17.533 & 4.671 \\
0.25 & Present work & 11.613 & 18.734 & 15.514 & 4.548 \\
& Ansys & 11.395 & 18.378 & 15.258 & 4.072 \\
\multirow{2}{*}{0.5} & Present work & 9.482 & 15.296 & 12.667 & 3.713 \\
\multirow{2}{*}{0.75} & Ansys & 9.341 & 15.05 & 12.529 & 3.35 \\
& Present work & 6.704 & 10.816 & 8.957 & 2.626 \\
\hline
\end{tabular}

Table 10,

Dimensionless natural frequency $\left(\bar{\omega}=\omega_{o} a^{2} \sqrt{\rho_{c} / E_{2}} / h\right),\left[\begin{array}{lll}30 & -30 & 30\end{array}\right]$ plates of different boundary conditions, $\left(E_{1} / E_{2}=2.45, G_{12}=0.48 E_{2}, v_{12}=0.23 \mathrm{a}=\mathrm{b}\right)$.

\begin{tabular}{lllll}
\hline $\mathbf{D}$ & References & SSSS & CCCC & SCSC \\
\hline \multirow{2}{*}{0} & Present work & 7.311 & 13.02 & 9.949 \\
& Ansys & 7.237 & 13.04 & 9.913 \\
0.25 & Present work & 6.332 & 11.289 & 8.619 \\
& Ansys & 6.272 & 11.359 & 8.595 \\
0.5 & Present work & 5.171 & 9.223 & 7.04 \\
0.75 & Ansys & 5.124 & 9.334 & 7.027 \\
& Present work & 3.657 & 6.526 & 4.98 \\
& Ansys & 3.625 & 6.653 & 4.978 \\
\hline
\end{tabular}



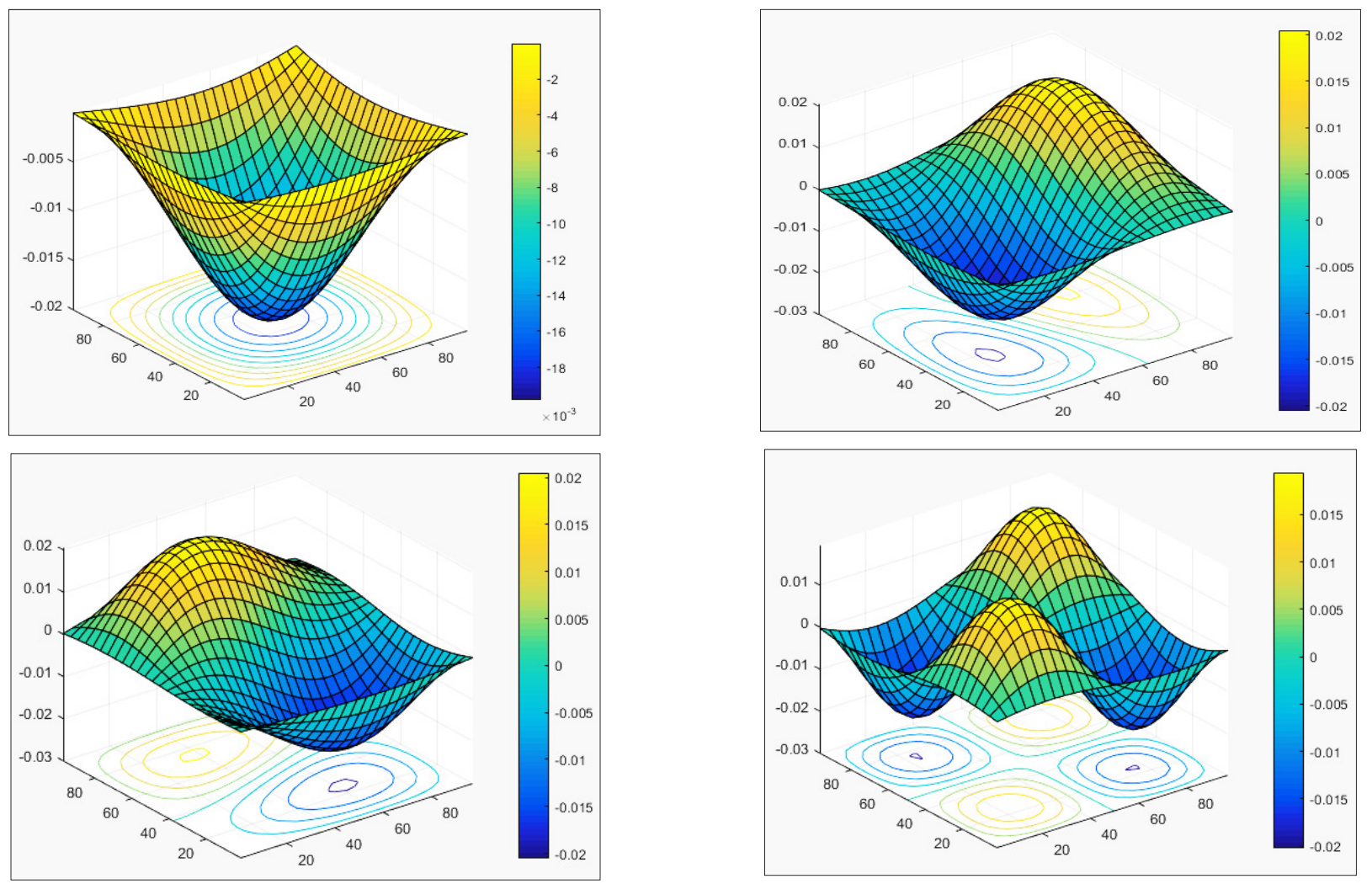

Fig. 2. Mode shape for free vibration of (SSSS) for [ 30 -30 30] laminated square plate a-first b-second c-third dfourth modes.

\section{Table11,}

Dimensionless natural frequency $\left(\bar{\omega}=\omega_{o} a^{2} \sqrt{\rho_{c} / E_{2}} / h\right)$, for [0 9090 0] (SSSS) plates with effect of aspect and modulus ratios, $\left(G_{12}=0.5 E_{2}, v_{12}=0.25\right)$ (natural frequency without load) $\mathrm{d}=0.5$.

\begin{tabular}{lllll}
\hline References & $\mathbf{a} / \mathbf{b}$ & $\boldsymbol{E}_{\mathbf{1}} / \boldsymbol{E}_{\mathbf{2}} \mathbf{1 0}$ & $\mathbf{2 5}$ & $\mathbf{4 0}$ \\
\hline \multirow{2}{*}{ Present work } & & 6.275 & 9.654 & 12.125 \\
& & $(8.875)$ & $(13.652)$ & $(17.147)$ \\
Ansys & 0.5 & 6.275 & 9.63 & 12.066 \\
& & $(8.875)$ & $(13.62)$ & $(17.064)$ \\
Present work & & 7.426 & 10.774 & 13.306 \\
& & $(10.502)$ & $(15.237)$ & $(18.817)$ \\
Ansys & 1 & 7.411 & 10.731 & 13.22 \\
& & $(10.48)$ & $(15.176)$ & $(18.702)$ \\
Present work & & 10.157 & 13.964 & 16.938 \\
\multirow{2}{*}{ Ansys } & & $(14.364)$ & $(19.748)$ & $(23.954)$ \\
& \multirow{2}{*}{1.5} & 10.161 & 13.964 & 16.934 \\
& & $(14.367)$ & $(19.747)$ & $(23.948)$ \\
\hline
\end{tabular}

\section{Nomenclature}

$\begin{array}{ll}\text { Symbol } & \begin{array}{l}\text { Discretion } \\ \text { A }\end{array} \\ \text { Length of a plate } \\ \text { H } & \text { width of a plate } \\ \text { A } & \begin{array}{l}\text { Plate thickness } \\ \text { vector of the expansion } \\ \text { or Rayleigh-Ritz coef- } \\ \text { ficients }\end{array} \\ A_{m n} & \begin{array}{l}\text { expansion or Rayleigh- } \\ \text { Ritz coefficients }\end{array}\end{array}$

$a_{m} \quad$ expansion or RayleighRitz coefficient $\begin{array}{ll}D_{i j} & \text { flexural rigidity } \\ M, N & \text { numbers of expansion }\end{array}$ terms used in $\mathrm{x}$ - and $\mathrm{y}$ direction, respectively

$M_{x}, M_{y}, \quad$ Moment result per unit $\quad \mathrm{N} . \mathrm{m} / \mathrm{m}$ $M_{x y} \quad$ length

$Q_{x} \cdot Q_{Y} \quad$ Transverse shear force $\mathrm{N}$ result

$K_{x 0}, K_{x 1} \quad$ rotational stiffness at $\quad$ Rad.N/m 


\begin{tabular}{|c|c|c|}
\hline & $\mathrm{x}=0$ and & \\
\hline$K_{y 0}, K_{y 1}$ & $\begin{array}{l}\text { a, respectively } \\
\text { rotational stiffness at } \\
y=0 \text { and } \\
b, \text { respectively }\end{array}$ & Rad.N/m \\
\hline$k_{x 0}, k_{x 1}$ & $\begin{array}{l}\text { translational stiffness } \\
\text { at } \mathrm{x}=0\end{array}$ & $\mathrm{~N} / \mathrm{m}$ \\
\hline$k_{y 0}, k_{y 1}$ & $\begin{array}{l}\text { and } a, \text { respectively } \\
\text { translational stiffness } \\
\text { at } \mathrm{y}=0 \\
\text { and } \mathrm{b} \text {, respectively }\end{array}$ & $\mathrm{N} / \mathrm{m}$ \\
\hline$P(x)$ & $\begin{array}{l}\text { a simple polynomial } \\
\text { function }\end{array}$ & \\
\hline $\mathrm{x}, \mathrm{y}, \mathrm{z}$ & $\begin{array}{l}\text { Cartesian coordinate } \\
\text { system }\end{array}$ & M \\
\hline$\Pi$ & $\begin{array}{l}\text { Total potential energy } \\
\text { of the System }\end{array}$ & N.m \\
\hline $\mathrm{U}$ & $\begin{array}{l}\text { Strain energy of defor- } \\
\text { mation }\end{array}$ & N.m \\
\hline$V_{c}$ & $\begin{array}{l}\text { the elastic potential en- } \\
\text { ergy }\end{array}$ & N.m \\
\hline $\mathrm{W}(\mathrm{x})$ & $\begin{array}{l}\text { flexural displacement of } \\
\text { a beam }\end{array}$ & M \\
\hline $\mathrm{W}(\mathrm{x}, \mathrm{y})$ & $\begin{array}{l}\text { flexural displacement of } \\
\text { a plate }\end{array}$ & $\mathrm{M}$ \\
\hline $\begin{array}{l}X(x) \\
Y(y)\end{array}$ & $\begin{array}{l}\text { beam characteristic } \\
\text { function }\end{array}$ & \\
\hline$\alpha_{0}, \quad \alpha_{1}$ & $W^{\prime \prime \prime}(a), W^{\prime \prime \prime}(0)$ & \\
\hline$\beta_{0}, \quad \beta_{1}$ & $W^{\prime}(0), W^{\prime}(a)$ & \\
\hline$\varphi_{m}^{a}(x)$ & $\begin{array}{l}\text { admissible functions in } \\
\mathrm{x} \text { direction }\end{array}$ & \\
\hline$\varphi_{n}^{b}(y)$ & $\begin{array}{l}\text { admissible functions in } \\
\mathrm{y} \text { direction }\end{array}$ & \\
\hline $\mathrm{S}, \mathrm{C}, \mathrm{F}$ & Simply- clamped- free & \\
\hline
\end{tabular}

\section{References}

[1]Zhong, Hongzhi, and Chao Gu. "Buckling of symmetrical cross-ply composite rectangular plates under a linearly varying in-plane load." Composite structures Vol. 80 No.1 (2007): PP. 42-48.

[2]Shufrin, I., O. Rabinovitch, and M. Eisenberger. "Buckling of symmetrically laminated rectangular plates with general boundary conditions-A semi analytical approach." Composite Structures Vol. 82 No.4 (2008) PP: 521-531.

[3]Kuo, Shih-Yao, and Le-Chung Shiau. "Buckling and vibration of composite laminated plates with variable fiber spacing" Composite Structures Vol. 90 No.2 (2009) PP: 196-200.

[4]Kim, Seung-Eock, Huu-Tai Thai, and Jaehong Lee. "Buckling analysis of plates using the two variable refined plate theory."Thin-Walled Structures Vol. 47 No. 4 (2009) PP: 455-462.

[5]Kumar Panda, Sarat, and L. S. Ramachandra. "Buckling and postbuckling behavior of crossply composite plate subjected to nonuniform in-plane loads." Journal of engineering mechanics Vol. 137 No. 9 (2011) PP: 589-597.

[6]Carrera, E., et al. "Effects of in-plane loading on vibration of composite plates." Shock and Vibration Vol. 19 No. 4 (2012) PP: 619-634.

[7]Thai, Huu-Tai, and Dong-Ho Choi. "A simple first-order shear deformation theory for laminated composite plates." Composite Structures Vol. 106 (2013) PP: 754-763.

[8]Sayyad, ATTESHAMUDDIN S., and Y. M. Ghugal. "Buckling and free vibration analysis of orthotropic plates by using exponential shear deformation theory." Latin American Journal of Solids and Structures Vol. 11 No. 8 (2014) PP: 1298-1314.

[9]Firas Hamzah Taya., "Buckling and Vibration Analysis of Laminated Composite Plate', M.Sc. Thesis, University of Baghdad, Mech. Dep. 2014.

[10] Mantari, J. L., and F. G. Canales. "Free vibration and buckling of laminated beams via hybrid Ritz solution for various penalized boundary conditions." Composite Structures Vol. 152 (2016) PP: 306-315

[11] Khov, Henry, Wen L. Li, and Ronald F. Gibson. "An accurate solution method for the static and dynamic deflections of orthotropic plates with general boundary conditions." Composite Structures Vol. 90 No. 4 (2009) PP: 474-481.

[12] Li, Wen L. "Vibration analysis of rectangular plates with general elastic boundary supports." Journal of Sound and Vibration Vol. 273 No. 3 (2004) PP: 619-635

[13] Li, Wen L. "Free vibrations of beams with general boundary conditions." Journal of Sound and Vibration Vol. 237 No. 4 (2000) PP: 709-725.

[14] Li, W. L., and M. Daniels. "A Fourier series method for the vibrations of elastically restrained plates arbitrarily loaded with springs and masses." Journal of Sound Vibration Vol. 252 (2002) PP: 768-781

[15] Reddy, Junuthula Narasimha. Mechanics of laminated composite plates and shells: theory and analysis. CRC press, 2004. 


\title{
تحليل الإبعاج والاهتزاز لصفائح مركبة طبقية مع ظروف أسناد عامة
}

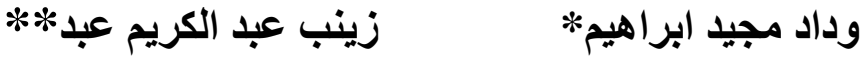

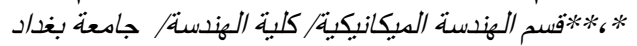 \\ *البريد الالكتروني: wedad.ibrahim@coeng.uobaghdad.edu.iq \\ zainabkareem2158@gmail.com البريد الالكتروني:****
}

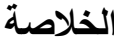

تمت دراسة الاهتزاز والانبعاج للصفائح الرقيقة المركبة المكونة من الطبقات المعرضة لاحمال منتظمة ضمن مستوى الصفيحة بأستخدام نظرية

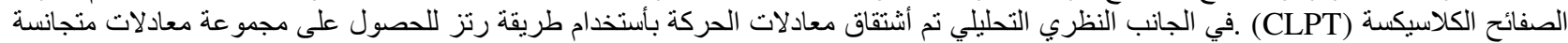

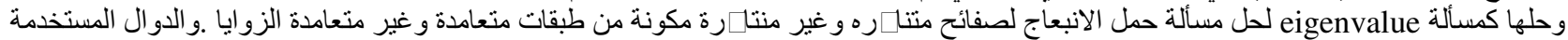

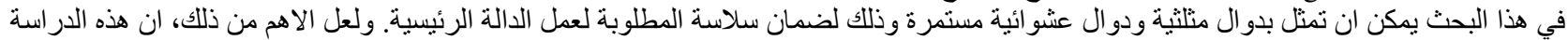

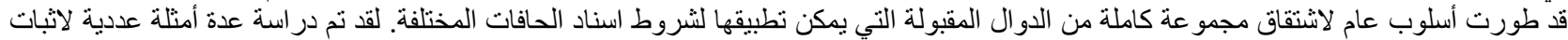

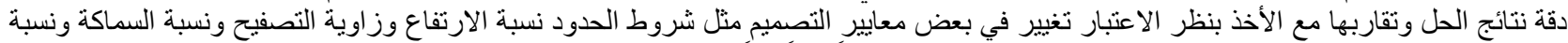

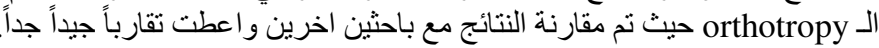

